\title{
Development of Mathematics E-Books in Improving Mathematical Literacy and Entrepreneurial Spirit
}

\author{
Rizki Amalia1, Fadilah², Mamay Komarudin3, Jaka Wijaya Kusuma4 \\ DOI: $10.35445 /$ alishlah.v13i3.987
}

\begin{abstract}
Article Info Abstract
Keywords:

Math E-Book;

Mathematical Literacy;

Entrepreneurial Spirit

This study aimed to create an e-book on mathematics learning for vocational high school students in grade XI, complete with liner program material, using the ADDIE model development methodology (Analysis, Design, Development, Implementation, Evaluation). Based on the findings of the development of ebooks on linear programming material for grade XI students at vocational high school in Langsa Aceh majoring in Online Business and Marketing, it can be concluded that the media is valid for use in learning mathematics with linear programming materials, then effective in improving mathematical literacy and entrepreneurial spirit. Finally, practical media is used in mathematics learning, among other conclusions.
\end{abstract}

Kata kunci:

E-Book Matematika;

Literasi Matematis;

Jiwa Kewirausahaan

\begin{abstract}
Abstrak
Tujuan penelitian ini adalah mengembangkan e-book pada pembelajaran matematika SMK kelas XI dengan materi program linier dengan menggunakan metode pengembangan model ADDIE (Analysis, Design, Development, Implementation, Evaluation). Pada tahap analisis dilakukan analisis terhadap konten materi, kemudian tahap mendesain e-book dan kemudian tahap pengembangan dilakukan uji validasi terhadap produk yang dikembangkan dan terakhir tahap implementasi dan evaluasi. Berdasarkan hasil pengembangan e-book pada materi program linier pada siswa Kelas XI SMK Langsa Aceh jurusan Bisnis Daring dan Pemasaran menunjukan bahwa media tersebut valid digunakan dalam pembelajaran matematika materi program linier, kemudian efektif dalam meningkatkan literasi matematis dan jiwa kewirausahaan dan terakhir media praktis digunakan dalam pembelajaran matematika.
\end{abstract}

\section{INTRODUCTION}

Learning is essentially a process of transforming knowledge from educators to students. A good learning process requires cross-information between students and students, but more importantly, there is the mutual information between students and other students (Fauziddin et al., 2021;

\footnotetext{
${ }^{1}$ Universitas Samudra, Langsa, Indonesia

Email: rizkiamalia@unsam.ac.id

2 Universitas Samudra, Langsa, Indonesia

Email: fadilah@unsam.ac.id

3 Universitas Bina Bangsa, Indonesia

Email: mamaykomarudin@binabangsa.ac.id

4 Universitas Bina Bangsa, Indonesia

Email: jakawijayakusuma@binabangsa.ac.id
} 
Sieckmann et al., 2020; Tandiling, 2015). However, when something unexpected happens, the world experiences an outbreak known as the COVID-19 pandemic. The covid pandemic requires educators to conduct distance learning that uses internet technology as a bridge (Abidah et al., 2020; Chandasiri, 2020; Di Pietro et al., 2020; Marinoni et al., 2020). This is because almost all schools have closed the learning process with the aim that the spread of this epidemic can be suppressed. The government thinks that schools are places where the virus can spread, and it is feared that the virus could spread to school residents, including students, teachers and others.

Such a world of education is a challenge for teachers to carry out an effective learning process to improve students' abilities and understanding of the material. Especially mathematics subjects need media that can bridge the learning process so that the knowledge process can be effective and efficient. Mathematics is a science that becomes the foundation in the development of science and technology, so efforts need to be made to carry out learning optimally. Mathematics provides the concept of reasoning and analogy (Kramarski \& Mevarech, 2003; Lithner, 2000; Marsitin, 2016; Rosita, 2014). Mathematics provides opportunities for students to be trained in logic through the mathematics learning process.

There is a need for learning media following current conditions where students must learn anytime and anywhere. The press created must, of course, optimize students' abilities in the learning process in the current pandemic situation. E-Book is one of the tools that mathematics teachers in the learning process can use during a pandemic. E-Books are easy to use and can be run on android media, commonly used by students in online learning (Letchumanan \& Tarmizi, 2011; Mouri et al., 2018). Several studies on E-Books show that a well-structured E-Book will improve students' ability to understand the material they are studying.

E-books, which stand for the electronic book, are one media that educators can use to deliver learning during a pandemic. E-books have features including being easy to use and adding animations and videos in the manufacturing process (Pujiastuti \& Haryadi, 2018; Shiratuddin et al., 2014). Some of the applications used to create e-books are flip bookmakers. This application is easy to use, and we can change the storage in HTML 5 form to be played in the browser or changed in the form of an android application. E-Books are designed to learn independently because of the ease with which it is easy to do automatic repetition in its use.

E-Book itself is a development from printed or conventional books to digital books. Through E-Books, there is no need to print because they can be accessed directly by users through applications that have been created and adjusted. E-Books have various types of file formats, including PDF ( Portable Digital Format ) developed by Adobe, EPUB ( Electronic Publication ), which is a format formed by the Open Forum of the International Digital Publishing Forum (IDPF), (AZW (Amazon Word), MOBI (MobiPocket) and PRC ( Product Representation Compact ) (Herdianto et al., 2021; Hwang \& Lai, 2017; Muqarrobin \& Kuswanto, 2016; Roskos et al., 2017). in the field of computers in the process of making teaching materials that can be used instantly and easy to use for users E-books can also be used for purposes of quickly finding the material to be studied because the system is made in the form of a search, meaning that users can search for sub material to be understood.

The development of e-books in mathematics learning has been widely developed by several researchers, including (Figueiredo et al., 2016; Lisa \& Wedyawati, 2020); the results of both studies show that effective e-book development can improve students' ability to learn mathematics, then a survey conducted by (Smith, 2015) that a well-written e-book can increase one's entrepreneurship. Based on this research, it is clear that e-books can be used to improve mathematical literacy skills, which is an essential ability in this century because Indonesia's mathematical literacy results are still below those of other countries. The entrepreneurial spirit needs to be developed in vocational students so that vocational students are prepared in addition to the world of work and the business world to be involved in.

E-Books are expected to develop the abilities expected by teachers, one of which is mathematical literacy. Mathematical literacy is an ability. PISA 2015 defines mathematical literacy 
as the ability of each individual to formulate, use and interpret mathematics in various contexts. Mathematical literacy can help students understand the importance of mathematics in real-world contexts. Mathematical literacy has become a hot issue in recent years because the context is closely related to the real world; problems in everyday life in mathematics have a lot to do with the context of mathematical literacy.

Indonesia is a country whose literacy skills still need to be improved. PISA results show that Indonesia is still below countries in Southeast Asia, especially Singapore and Thailand. It needs war and from all parties whose spearhead is the teacher in developing this mathematical literacy ability. Three things are the foundation for understanding mathematical literacy: (1) the ability to apply, formulate, and interpret mathematics in various contexts. This means that the world of mathematics can be presented in several real contexts closely related to students' daily lives to learn from these problems. (2) Mathematical reasoning is a deep foundation and is a tool for describing, explaining and interpreting various phenomena. The reasoning is the key in the process of someone being mathematically literate. (3) utilizing mathematical literacy to help someone apply mathematics to everyday life (Mariani \& others, 2018; Munadi et al., 2020; Sumirattana et al., 2017). The concept in formulating mathematical literacy can be described as follows:

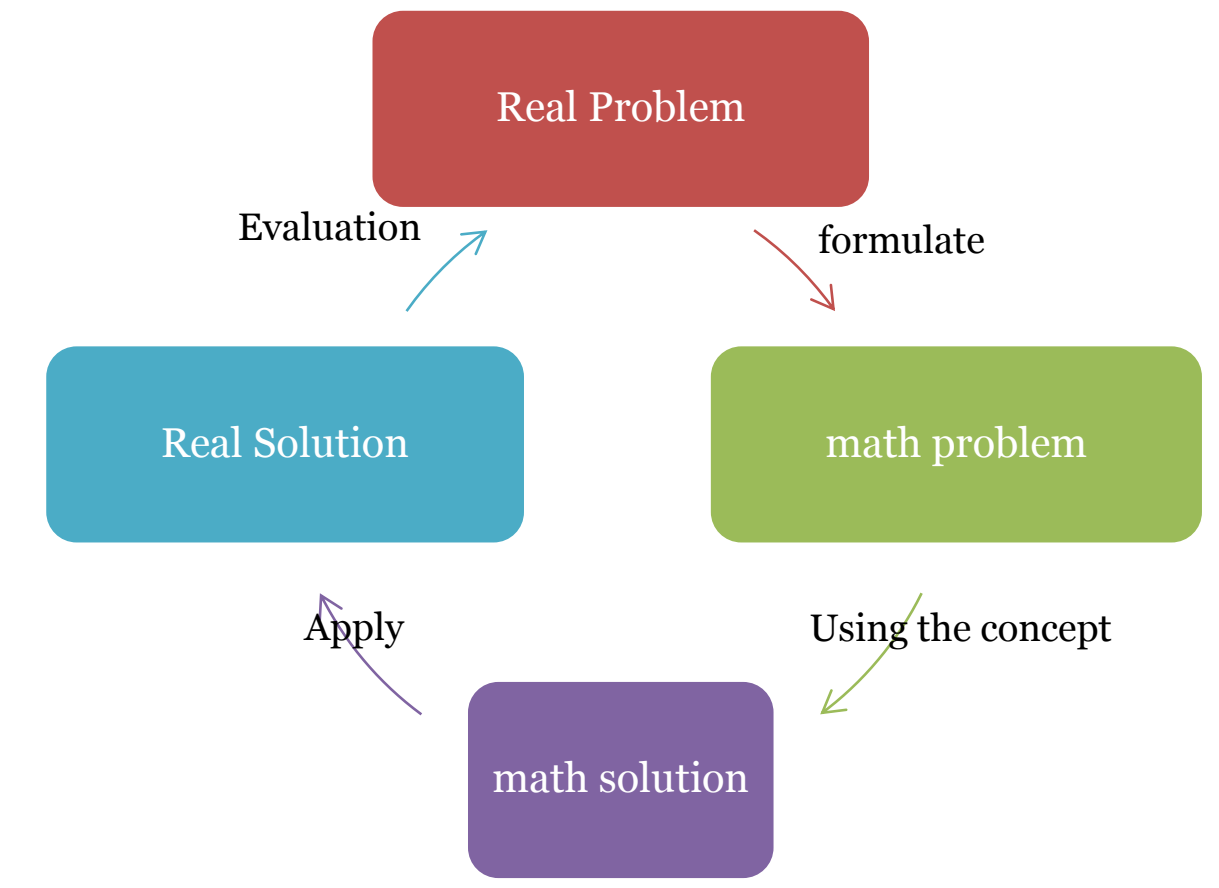

\section{Figure 1. The process of mathematical literacy according to the OECD in the OECD 2016 (Amir et al., 2019)}

The essential abilities that form the foundation of mathematical literacy are mathematical communication, mathematization, representation, reasoning, strategy design, use of symbols, use of tools in a mathematical context. These abilities become the foundation of students in developing their mathematical literacy skills. The content of mathematical literacy includes changes and relationships, space and shape, quantity, and uncertainty and data (Putri \& others, 2019; Sumirattana et al., 2017). This content is the standard used today and becomes content in mathematics in its development.

Besides, mathematical literacy, which is no less critical in welcoming modern competition in this century, is how students are entrepreneurial in implementing learning. Often people associate that entrepreneurship is always related to the world of business or trade. The meaning is not wrong, but more than that, entrepreneurship has a broader sense; if someone gives more value than an item, he should already have a high entrepreneurial spirit. Someone who can add value from a used drink 
bottle and then decorate it as a pencil case has applied the spirit of entrepreneurship. Critical and creative ideas often appear in a person's process to develop his entrepreneurial spirit (Supardi et al., 2018). This is because innovative ideas are an integral part of the entrepreneurial spirit. Aside from the two ideas, of the most emerging attitudes is the disciplined attitude possessed by a high entrepreneurial mentality. Discipline is the foundation of a person in addition to the honesty of that person. Through discipline, people can achieve the desired goals and ideals.

The current competition era allows students to compete, especially in this century's absence of economic restrictions. Students need to be taught and familiarized with the nature of entrepreneurship to instil the essence of entrepreneurship in their daily lives. It should be realized or not that entrepreneurship will emerge if someone has strong independence (Nasukha et al., 2020; Ulya \& Istiandaru, 2018). Learning independence needs to be trained in the learning process to take responsibility for what he is doing. Through this research, the author hopes that the development of this product can show that E-Books can help students understand mathematical literacy and the entrepreneurial spirit so that E-Books can become a digital platform and alternative by educators in the learning process carried out, especially in learning mathematics.

\section{METHODS}

This research uses Research and Development (R\&D) research methods. R\&D research is research to develop and validate a product. The development stage used uses an R\&D design. The development stages used to use the ADDIE ( Analysis, Design, Development, Implementation, Evaluation ) model with the following steps :

Analysis

The analysis is used to see the needs of students regarding teaching materials that follow the interests and talents of students in learning mathematics. The product developed must be following the needs of students in learning mathematics. Then analyze the content of the material presented in the form of an E-Book so that it is easily accessible by students.

Design

This stage is a stage in the preparation of e-book media that students will use. This stage is essential in preparing the e-book media used, starting from the appearance of the e-book used and the material presented in the form of an e-book. At this stage, it is based on the results of the analysis that the research team has compiled.

\section{Development}

The development stage is the stage that is carried out after the e-book design has been made, and then a feasibility test is carried out by the experts to ensure that the e-book can be used and served for students. This process is carried out in two stages: 1) conducting an assessment from experts consisting of media experts, especially graphic design and material experts in mathematics, 2) small class trials, to conduct experiments on e-books used in small groups that have been determined. Research team

Implementation

This stage is an advanced stage of the development stage. The product in the form of an e-book that has been revised is then finalized so that students can appropriately use the product in the form of an e-book. This stage also implements the products used in the learning of class X SMK students. Evaluation

Evaluation is the final stage of the development used, namely evaluating the media used.

\section{FINDINGS AND DISCUSSION}

The results of this study are more aimed at the development used in developing learning media in the form of e-books on linear programming material that vocational students in learning mathematics can use. This e-book is named Si-Cerdik, hoping that it will be easy for students to remember. An explanation of the stages of development is as follows: 


\section{Analysis}

This stage is the initial stage in developing learning media in an e-book. Based on the analysis of student needs, vocational students already use communication tools or known as mobile phones, using android media so that the development of e-books can be used in learning mathematics using e-books. The curriculum's analysis was that the material for linear programming was mainly related to economic activities with linear inequalities material. Then the mathematical model was determined to determine the maximum value of mathematical problems related to linear programming material.

\section{Design}

The design stage is developing the e-book media created by the research team. This stage is making e-books starting from the design prepared for mathematics learning at SMK 1 Langsa, Aceh Regency. The initial appearance of the created e-book is as follows:

The initial appearance of the e-book is made by combining several colours to make it look attractive and can be an attraction for students. Then on the opening page, there is a guide to studying the e-book. This guide is intended to use this e-book as a step in learning mathematics on linear programming material.

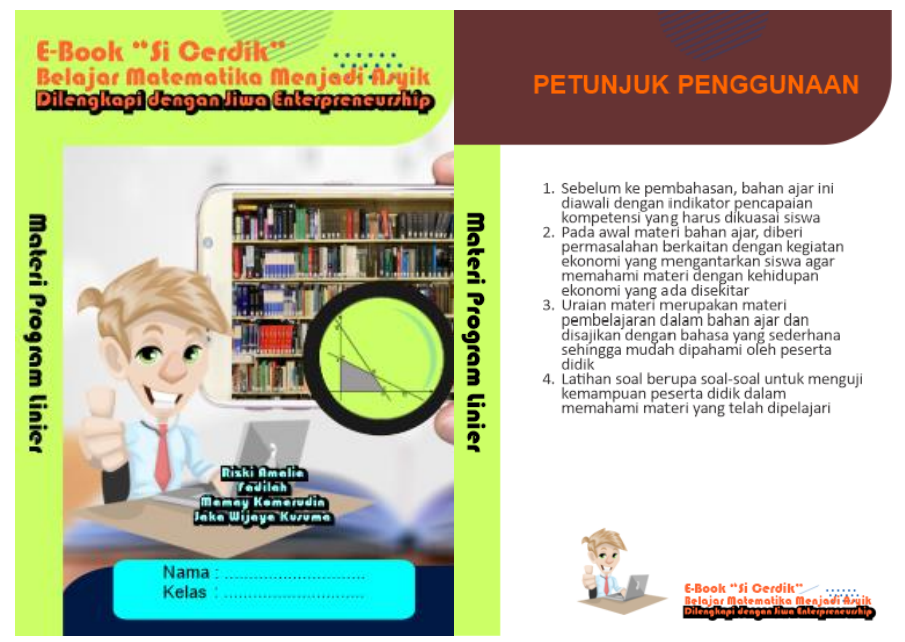

Figure 2. The Initial Screen of Smart E-Books and Instructions for Using E-Books

The following figure shows daily problems shown in economic activity, which refers to difficulties regarding linear programming. This is made so that students can understand mathematics related to everyday life. Then at the beginning, the principle of an entrepreneurial spirit must be provided solutions by students in understanding problems related to economic activities

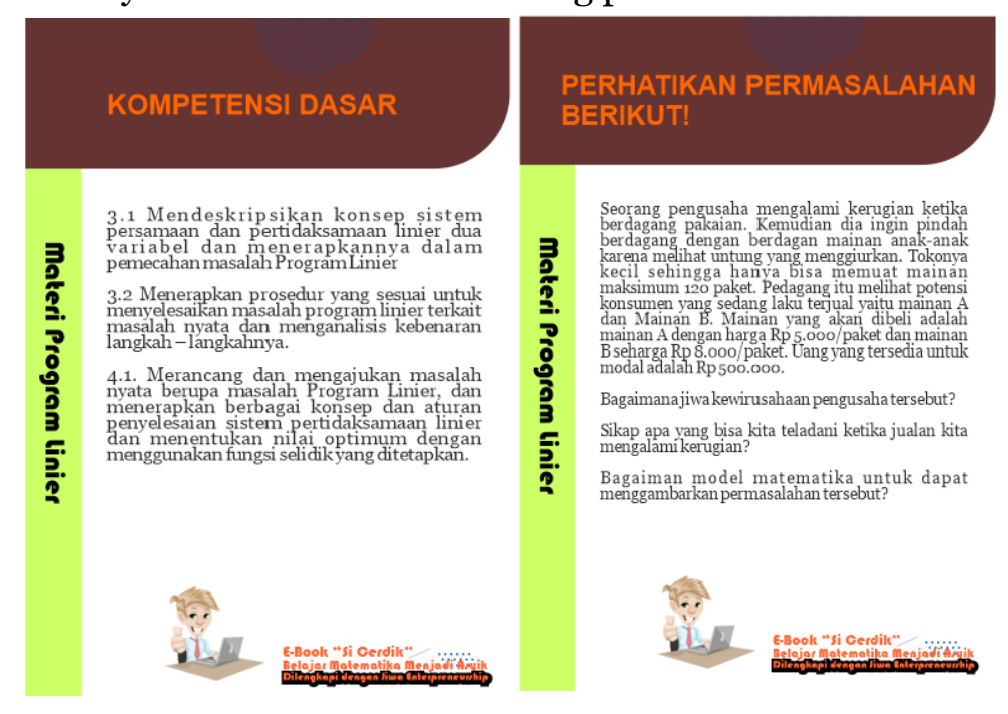

Figure 3. Display of Basic Competencies and Problems Relating to Daily Life in Economics 
The problems presented contain problems of economic activity that have to do with Linear Program Materials in Vocational Schools. This is why SMK students are students who are prepared, one of which is to be ready for entrepreneurship and being prepared in the world of work. Instilling an entrepreneurial spirit is essential so that students can familiarize themselves with the attitudes of a true entrepreneur, for example, never giving up on having creative ideas and others. In addition, at the end of the activity, exercises were also given to check students' understanding. The display is as follows:

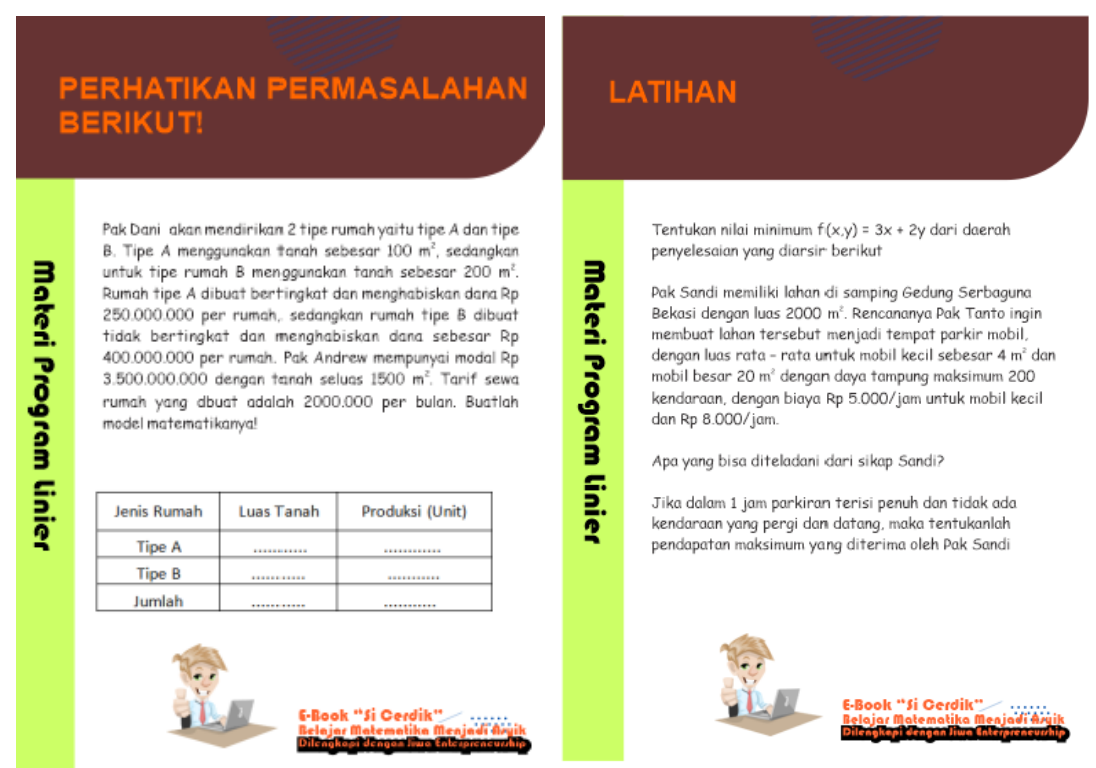

Figure 4. Display of Problems and Exercises

\section{Development}

This stage is the third stage of the E-Book product development process on linear program material in SMK. The following things were carried out at this stage: 1) expert validation of e-books on linear programming material, which consisted of media and graphic design experts and then content experts on mathematical material. There are 20 questions regarding this validation, ten questions regarding ease of reading and colour combinations in the display and ten questions regarding the material presented. The validation results become the primary suggestions in product development which will be revised based on inputs and criticisms from the validators, 2) the second stage is product revision; product revision is an improvement on e-books made to make it easier for students to understand the material. The input results from the validator are presented in the following table

\section{Table 1. Product Revision}

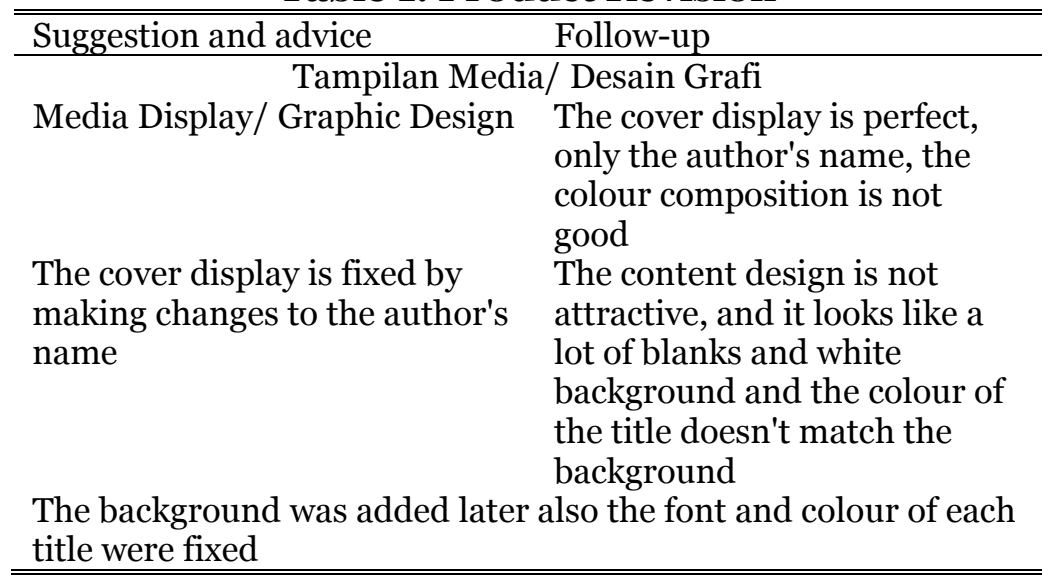




\begin{tabular}{ll}
\hline \hline $\begin{array}{l}\text { Increase practice questions so } \\
\text { that students can improve their } \\
\text { abilities }\end{array}$ & Add practice questions \\
$\begin{array}{l}\text { The entrepreneurial spirit } \\
\text { needs to be familiarized with } \\
\text { how to practice or experiment } \\
\text { at home }\end{array}$ & $\begin{array}{l}\text { Assignment to design a } \\
\text { business at home and } \\
\text { assigned to students }\end{array}$ \\
\hline \hline
\end{tabular}

\section{Implementation}

This stage is implementing a product that has been developed and revised based on the input from the validator. The product is applied in class XI SMK Langsa Aceh. The results of the pretest and then the posttest, the practicality of the media and the student's responses became the material for disseminating this e-book for learning facilities for vocational students

\section{Evaluation}

The evaluation stage is the final stage of the development of the media created; at this stage, the weaknesses and shortcomings of the media can be seen from the results that have been achieved in the implementation stage. This evaluation show that the two validators scored $82 \%$ for the media and graphic design validators. In contrast, the content validators scored $84 \%$ of the total 20 statements given in a good category. The effectiveness of the product is based on the results of the pretest and posttest conducted in Class XI of SMK Langsa Aceh, Department of Online Business and Marketing, by providing mathematical literacy questions, with the scores obtained from students as follows:

\begin{tabular}{cc}
\multicolumn{2}{c}{ Table 2. Pretest and Posttest } \\
\hline \hline Prestest & Posttest \\
average & Average \\
53 & 78 \\
93 students & 93 students \\
\hline \hline
\end{tabular}

These results illustrate that students' mathematical literacy skills have increased even though it does not increase significantly. But E-Books can improve the mathematical literacy skills of SMK $\mathrm{N} 1$ Langsa Aceh students. These results illustrate that e-books are considered effective in improving the mathematical literacy skills of SMK students.

Students can easily use e-Books without knowing the limitations of distance and time. Every student can easily access the e-book to be able to learn mathematics. The understanding presented in the e-book is in daily problems that have to do with economic activities. This is very effective in familiarizing vocational students, especially those majoring in Business and Management, in understanding financial issues.

In addition, through the provision of problems, students understand the nature or character that a true entrepreneur must possess. This planting is essential so that when they become entrepreneurs, they are not discouraged and look for ideas and innovations in providing products that can satisfy consumers. Students give different responses in learning mathematics that mathematics subjects are also related to the business world, which is a provision for students in preparing for competition when they graduate from school. This is supported by the results of the questionnaire given to students regarding the product's practicality, namely the e-book that was made; the data processing results showed a percentage of $82.6 \%$ of the 20 statements given; these results were suitable category. Then the measurement is also about the entrepreneurial spirit to students with the results obtained, namely $78.2 \%$ in the excellent variety. Good that learning mathematics through e-books prepared by the research team can increase students' entrepreneurial spirit. Some students even commented that learning mathematics is fun, and we can learn how to be a promising entrepreneurs.

These results illustrate that e-books effectively improve students' mathematical literacy skills and entrepreneurial spirit. Through e-books that are packaged attractively, especially on the 
problems given to students, they can increase interest and motivation in learning mathematics. Some students become aware of the role of mathematics in everyday life, especially in terms of economic activities. The results of this study are also supported by research (Bayani, 2019; Figueiredo et al., 2016). This study indicates that the development of e-books in learning mathematics can improve mathematical abilities. Therefore e-books that are well prepared and planned can benefit vocational students in learning mathematics and enhance their entrepreneurial spirit.

This study illustrates that systematically developed e-books can improve students' mathematical literacy skills and entrepreneurial spirit. Mathematical literacy can improve because the e-book designed is easy to use for students in learning mathematics, and students can easily repeat the material in the e-book. This is following the opinion (Pujiastuti \& Haryadi, 2018; Shiratuddin et al., 2014) that the features in e-books are easy to use so that students can easily use them. Then other results regarding the entrepreneurial spirit can be improved by applying problems in everyday life that are close to the world of SMK to be used as problems at the beginning of learning so that students can understand the characteristics of entrepreneurship that need to be developed in the business world after they graduate at the SMK unit.

\section{CONCLUSION}

Based on the results of the development of e-books on linear programming material for Class XI students of SMK Langsa Aceh majoring in Online Business and Marketing, it shows that the media is valid for use in learning mathematics with liniear programming material, then influential in improving mathematical literacy and entrepreneurial spirit and finally practical press is used in mathematics learning. This research is limited to developing e-books designed using e-book applications to improve mathematical literacy and entrepreneurial spirit. However, it is necessary to create other media for further analysis outside of e-books that students can easily use.

\section{REFERENCES}

Abidah, A., Hidaayatullaah, H. N., Simamora, R. M., Fehabutar, D., \& Mutakinati, L. (2020). The impact of covid-19 to indonesian education and its relation to the philosophy of "merdeka belajar." Studies in Philosophy of Science and Education, 1(1), 38-49.

Amir, M. F., Mufarikhah, I. A., Wahyuni, A., Nasrun, N., \& Rudyanto, H. E. (2019). Developing 'Fort Defending'Game as a Learning Design for Mathematical Literacy Integrated to Primary School Curriculum in Indonesia. Elementary Education Online, 18(3).

Bayani, A. (2019). Pengembangan E-book Matematika Berbasis Masalah Pada Materi Kubus Dan Balok SMP/MTS kelas VIII. Jurnal Pendidikan Matematika (JPM), 5(1), 7-15.

Chandasiri, O. (2020). The COVID-19: impact on education. Journal of Asian and African Social Science and Humanities, 6(2), 38-42.

Di Pietro, G., Biagi, F., Costa, P., Karpiński, Z., \& Mazza, J. (2020). The Likely Impact of COVID-19 on Education: Reflections based on the Existing Literature and Recent International Datasets. In Publications Office of the European Union, Luxembourg: Vol. EUR 30275 (Issue JRC121071). Publications Office of the European Union. www.stock.adobe.com

Fauziddin, M., Mayasari, D., \& Rizki, L. M. (2021). Effective Learning for Early Childhood during Global Pandemic. Al-Ishlah: Jurnal Pendidikan, 13(1), 515-522.

Figueiredo, M., Bidarra, J., \& Bostad, R. (2016). The development of an eBook for teaching and learning mathematics. International Conference on Universal Access in Human-Computer Interaction, 49-56.

Herdianto, E. N., Indriati, D., \& others. (2021). E-book Based on Mobile Learning Used Problem Based Learning (PBL) Model to Improve Problem-Solving Ability in Statistical Material. Journal of Physics: Conference Series, 1808(1), 12066.

Hwang, G.-J., \& Lai, C.-L. (2017). Facilitating and bridging out-of-class and in-class learning: An interactive e-book-based flipped learning approach for math courses. Journal of Educational Technology |\& Society, 2O(1), 184-197.

Kramarski, B., \& Mevarech, Z. R. (2003). Enhancing mathematical reasoning in the classroom: The effects of cooperative learning and metacognitive training. American Educational Research 
Journal, 4O(1), 281-310.

Letchumanan, M., \& Tarmizi, R. A. (2011). E-book utilization among mathematics students of Universiti Putra Malaysia (UPM). Library Hi Tech.

Lisa, Y., \& Wedyawati, N. (2020). Pengembangan Bahan Ajar E-Book Matematika Dasar Berbasis Metakognisi Menggunakan Flipbook Maker Untuk Mahasiswa Pendidikan Biologi Stkip Persada Khatulistiwa Sintang. VOX EDUKASI: Jurnal Ilmiah Ilmu Pendidikan, 11(1), 68-79.

Lithner, J. (2000). Mathematical reasoning in task solving. Educational Studies in Mathematics, 41(2), 165-190. https://doi.org/10.1023/A:1003956417456

Mariani, S., \& others. (2018). The analysis of mathematics literacy on PMRI learning with media schoology of junior high school students. Journal of Physics: Conference Series, 983(1), 12107.

Marinoni, G., Van't Land, H., \& Jensen, T. (2020). The impact of Covid-19 on higher education around the world. IAU Global Survey Report.

Marsitin, R. (2016). Kemampuan Penalaran dan Koneksi Matematis dalam Pembelajaran Matematika dengan Problem Solving. Jurnal Pendidikan Matematika (JPM), 2(1), 58-66.

Mouri, K., Uosaki, N., \& Ogata, H. (2018). Learning analytics for supporting seamless language learning using e-book with ubiquitous learning system. Journal of Educational Technology |\& Society, 21(2), 150-163.

Munadi, S., Febriyanti, W. D. R., \& others. (2020). Design and validation of mathematical literacy instruments for assessment for learning in Indonesia. Design and Validation of Mathematical Literacy Instruments for Assessment for Learning in Indonesia, 9(2), 865-875.

Muqarrobin, T. F., \& Kuswanto, H. (2016). Development of an android-based physics e-book to ease students physics learning And its influence on their learning achievement. American Journal of Engineering Research, 5(10), 223-229.

Nasukha, M., Muhyani, M., Nafisah, I. D., \& Sutisna, S. (2020). Melejitkan Jiwa Kewirausahaan Dan Prestasi Siswa Melaui Pembelajaran Matematika Berbasis Higher Order Thinking Skills (Hots). AKSIOMA: Jurnal Program Studi Pendidikan Matematika, 9(4), 936-949.

Pujiastuti, H., \& Haryadi, R. (2018). Interactive Math E-Book: An Alternative Learning Resources for 21st Century Learners. First International Conference on Technology and Educational Science.

Putri, R. I. I., \& others. (2019). New school mathematics curricula, PISA and PMRI in Indonesia. In School Mathematics Curricula (pp. 39-49). Springer.

Rosita, C. D. (2014). Kemampuan penalaran dan komunikasi matematis: Apa, mengapa, dan bagaimana ditingkatkan pada mahasiswa. Euclid, 1(1).

Roskos, K., Brueck, J., \& Lenhart, L. (2017). An analysis of e-book learning platforms: Affordances, architecture, functionality and analytics. International Journal of Child-Computer Interaction, $12,37-45$.

Shiratuddin, M. F., Smeda, A., \& Wong, K. W. (2014). Proposed framework of the adoption of ebook amongst mathematics and statistics students at universities in Libya.

Sieckmann, F., Petrusch, N., \& Kohl, H. (2020). Effectivity of Learning Factories to convey problem solving competencies. Procedia Manufacturing, 45, 228-233.

Smith, D. (2015). EBOOK: Exploring Innovation. McGraw Hill.

Sumirattana, S., Makanong, A., \& Thipkong, S. (2017). Using realistic mathematics education and the DAPIC problem-solving process to enhance secondary school students' mathematical literacy. Kasetsart Journal of Social Sciences, 38(3), 307-315.

Supardi, N., Rinaldi, A., \& others. (2018). Lembar Kerja Peserta Didik Berbasis Kegiatan Transaksi Kewirausahaan Materi Sistem Persamaan Linier Dua Variabel. Desimal: Jurnal Matematika, 1(1), 49-55.

Tandiling, E. (2015). Effectivity of Problem Based Learning (PBL) in improving students mathematical representation. Proceeding of International Conference On Research, Implementation, and Education of Mathematics and Sciences, 151.

Ulya, H., \& Istiandaru, A. (2018). Permainan pasaran dalam pembelajaran matematika materi aritmetika sosial untuk menumbuhkan karakter kewirausahaan. Seminar Nasional Pendidikan Matematika Ahmad Dahlan, 1, 88-93. 